\title{
Pengaruh Media Tanam pada Hidroponik terhadap Pertumbuhan dan Hasil Kailan (Brassica Oleracea L.)
}

\author{
The Effect of Hydroponic Growing Media on Growth and Yield of Kailan \\ (Brassica oleracea L.) \\ Gemah Nurifah, *Resti Fajarfika \\ Program Studi Agroteknologi, Fakultas Pertanian, Universitas Garut
} Jl. Raya Samarang No.52A, Tarogong Kaler, Kabupaten Garut, Jawa Barat 44151

E-mail: fajarfikaresti@gmail.com

\begin{abstract}
ABSTRAK
Peningkatan produksi sayuran dapat dilakukan dengan hidroponik. Penelitian ini bertujuan untuk mengetahui pengaruh beberapa media tanam terhadap pertumbuhan dan hasil kailan pada hidroponik. Penelitian menggunakan Rancangan Acak Lengkap yang terdiri atas 6 perlakuan (arang sekam, cocopeat, kapas, kerikil, rockwool, dan serbuk gergaji) dengan 4 ulangaan. Hidroponik menggunakan sistem nutrient film technique dengan sumbu. Hasil penelitian menunjukkan bahwa terdapat beda nyata antara perlakuan media arang sekam, cocopeat, kerikil, rockwool, dan serbuk gergaji terhadap tinggi tanaman, jumlah daun, bobot segar, dan bobot kering tanaman dibandingkan perlakuan kapas
\end{abstract}

Kata kunci : Media Tanam, Kailan, Hidroponik, AB Mix

\begin{abstract}
The crop production can increased with hydroponics. This research was aimed to determine the effect of various growing media on the growth and yield results of kailan. The research was arranged in a completely randomized design consisting of 6 treatments (husk charcoal, cocopeat, cotton, gravel, rock wool, sawdust) with 4 replication. The hydroponics used nutrient film technique and wick system. The result showed that there were significant among growing media treatments of husk charcoal, cocopeat, gravel, rockwool, sawdust in plant height, number of leaves, fresh and dry weight of plants compared cotton treatments.
\end{abstract}

Keywords: Growing Media, Kailan, Hydroponic, AB Mix

\section{PENDAHULUAN}

Kailan (Brassica oleraceae L.) merupakan sayuran yang memiliki nilai ekonomis tinggi. Umumnya yang dimanfaatkan adalah daunnya yang muda (baby kailan) karena rasanya yang lebih enak dan renyah (Pracaya, 2005). Kailan 
menunjang gizi masyarakat karena dalam 100 g kailan yang dikonsumsi mengandung vitamin A (7540 IU), vitamin C (115 mg), Ca (62 mg), Fe (2,2 mg), energi (kalori) $(35,00 \mathrm{kal})$, protein $(3,00 \mathrm{mg})$, lemak (40 gram), karbohidrat (6,80 $\mathrm{mg})$, serat $(1,20 \mathrm{gram})$, fosfor $(56,00 \mathrm{mg})$, vitamin B1 $(0,10 \mathrm{mg})$, vitamin B2 (0,3 mg), vitamin B3 (0,40 mg), dan air (28,00 mg) (Irianto, 2012). Kailan memiliki prospek yang tinggi karena diminati oleh masyarakat Indonesia dari kalangan menengah ke atas, banyak tersaji di berbagai restauran (Samadi, 2013), sehingga mempunyai nilai jual yang tinggi dan menjadi peluang usaha dalam budidaya pertanian.

Saat ini, permasalahan yang dihadapi dalam bidang pertanian salah satunya adalah upaya peningkatan produksi dengan kandungan residu pestisida yang rendah karena kesadaran masyarakat terkait pentingnya bahan pertanian khususnya sayuran bebas pestisida semakin meningkat. Selain itu, sempitnya lahan yang tersedia pada wilayah perkotaan atau perumahan untuk dijadikan lahan pertanian. Adanya alih fungsi lahan pertanian menyebabkan perlu rekayasa agar di lahan sempit tetap meningkatkan produksi pendapatan secara ekonomis maupun untuk keperluan hidup sehari-hari, yaitu dengan hidroponik.

Hidroponik adalah cara bercocok tanam tanpa menggunakan tanah melainkan menggunakan air sebagai suplai hara dan mineral terhadap pertumbuhan tanaman (Prihmantoro \& Indriani, 1999). Sistem hidroponik pada dasarnya merupakan modifikasi dari sistem pengelolaan budidaya tanaman di lapangan secara lebih intensif dengan tujuan untuk meningkatkan kuantitas dan kualitas produksi tanaman serta menjamin kontinuitas produksi tanaman (Rosliani \& Sumarni, 2005).

Keuntungan dari teknologi tersebut dapat menghemat biaya investasi sekitar $38 \%$, mampu menghasilkan sayuran yang dipersyaratkan pasar, pemberian nutrisi yang sesuai membuat tanaman sehat sehingga dapat bertahan dari serangan hama dan penyakit (Rahimah, 2012). Hidroponik dapat menggunakan sistem sumbu (Wick System) yaitu metode hidroponik yang memanfaatkan prinsip kapilaritas air, larutan nutrisi dari bak penampung menuju perakaran tanaman pada posisi di atas dengan perantara sumbu yang bahannya mudah menyerap air (Hendra \& Andoko, 2014). 
Selain itu, dapat juga menggunakan Sistem NFT (nutrient film technique) adalah teknik hidroponik dimana nutrisi dipompa ke tanaman melalui aliran air yang tipis, sehingga akar tumbuh bersentuhan dengan lapisan tipis nutrisi yang mengalir. Ketinggian lapisan air bisa diatur satu sampai dua sentimeter. Keuntungan dari sistem ini, ketika aliran listrik terputus maka cairan nutrisi masih tersisa didalam sistem. Konstruksi sistem dibuat bertingkat sehingga cairan nutrisi sampai pipa paling atas kemudian mengalir sampai pipa paling bawah, dan langsung kebawah penampungan cairan pupuk. Sistem ini banyak disukai karena akar tanaman menyerap lebih banyak oksigen dari udara dibandingkan yang diserap dari larutan nutrisi. Hal ini disebabkan karena hanya ujung akar saja yang bersentuhan dengan larutan nutrisi sehingga tumbuhan mendapatkan lebih banyak oksigen dan hal ini menyebabkan tumbuhan lebih cepat tumbuh dan berkembang (Adam, 2017).

Pemanfaatan media tanampun sederhana dapat menggunakan rockwool, cocopeat, arang sekam, batu krikil, kapas dan serbuk gergaji. Karakteristik media tanam yang baik memiliki ciri yaitu membuat unsur hara tetap tersedia, kelembaban terjamin, dan drainase baik. Media yang digunakan harus dapat menyediakan air, zat hara, dan oksigen, serta tidak mengandung zat racun bagi tanaman (Istiqomah, 2006). Tujuan penelitian ini mengetahui pengaruh berbagai media tanam terhadap pertumbuhan dan hasil kailan pada hidroponik.

\section{METODE PENELITIAN}

Penelitian dilakasanakan di Kecamatan Kersamanah, Kabupaten Garut pada tahun 2018. Bahan yang digunakan yaitu benih kailan varietas Winsa, kapas, arang sekam, cocopeat, rockwool, batu kerikil, serbuk gergaji, nutrisi AB mix dan air. Alat yang digunakan yaitu pipa PVC (Poly Vinyl Chlorid), ember, gelas ukur, stik kayu, penggaris, timbangan, netpot (tinggi $6 \mathrm{~cm}$ ), cutter dan TDS meter (Total Disolved Solid).

Penelitian menggunakan Rancangan Acak Lengkap (RAL) dengan enam perlakuan, yaitu M1= Rockwool, M2 = Kapas, M3 = Serbuk Gergaji, M4 = Cocopeat, M5 = Arang Sekam, M6 = Batu Kerikil. Setiap perlakuan diulang empat kali dan terdiri dari empat tanaman, sehingga terdapat 72 tanaman. 
Persiapan tempat. PVC (Poly Vinyl Chlorid) yang di desain sesuai untuk tanaman hidroponik, dengan sistem NFT (Nutrient Film Technique) dan sistem sumbu. Bagian atasnya berupa naungan plastik dan pada bagian pinggir ditutup kain kasa. Jarak antar tanaman $25 \mathrm{~cm}$ dan jarak antar perlakuan $10 \mathrm{~cm}$.

Persiapan bibit. Benih kailan disemai pada rockwool, setelah dua malam ditempat yang teduh kemudian dipindahkan ke tempat terbuka yang terlindungi oleh plastik UV dan penyiraman dilakukan setiap hari. Setelah umur 5 hari atau sudah berdaun 2, benih dipindahkan ke netpot dengan media tanam sesuai perlakuan.

Pelarutan nutrisi AB mix. Nutrisi AB mix (fertimx) dibuat dengan cara melarutkan nutrisi A (1 kg) dan B (1 kg) (masing-masing dilarutkan dalam 5 liter air) setelah dicampurkan semua bahan kemudian diaduk agar semua bahan larut dalam air. Selanjutnya jika larutan $\mathrm{AB}$ mix dipakai maka diambil sebanyak $300 \mathrm{ml}$ dan dimasukkan ke dalam drum yang berukuran 25 liter, drum tersebut diisi dengan air (20 liter), setelah itu nutrisi dicek kadar $\mathrm{pH}$ sekitar 5,5-6,6 dan kepekatannya, kemudian dialirkan ke setiap tanaman.

Variabel pengamatan yang diamati meliputi tinggi tanaman, jumlah daun, bobot segar per tanaman, bobot kering per tanaman. Tinggi tanaman diukur dari pangkal batang diatas permukaan media tanam sampai pucuk pada umur 14, 28 dan 35 HST (3 sampel per plot). Jumlah daun dihitung pada daun yang telah membuka sempurna pada umur 14, 28, dan 35 HST (3 sampel per plot). Bobot segar per tanaman dilakukan pada saat panen (40 HST) dengan cara membersihkan dari kotoran, kemudian ditimbang (3 sampel per plot). Bobot kering per tanaman dilakukan pada saat panen dengan cara dioven, suhu $60^{\circ} \mathrm{C}$ sampai kering konstan, kemudian ditimbang (1 sampel per plot).

\section{HASIL DAN PEMBAHASAN}

\section{Pengaruh media tanam hidroponik terhadap tinggi tanaman}

Hasil analisis menunjukkan bahwa pada 14 hari setelah tanam (HST) cocopeat memberikan tinggi tanaman tertinggi yaitu $8,33 \mathrm{~cm}$, hal ini mengindikasikan bahwa cocopeat mampu menyerap nutrisi dengan baik. Hal ini sesuai dengan pernyataan Agoes (1994) bahwa cocopeat dapat menyimpan air 
yang mengandung unsur hara dalam pori-porinya sehingga frekuensi pemupukan dapat dikurangi, daya serap air tinggi, mengandung unsur hara dari alam yang diperlukan tanaman, menunjung pertumbuhan akar dengan cepat sehingga baik untuk pembibitan. Menurut Rahmawati (2018) bahwa cocopeat mengandung unsur hara mikro yaitu tembaga $(\mathrm{Cu})$ yang berfungsi berperan dalam transpor elektron pada fotosintesis dan berperan didalam pembentukan akar, seng ( $\mathrm{Zn})$ berfungsi sebagai pertambahan pertumbuhan akar dan pelebaran daun.

Tinggi tanaman terendah ditunjukkan oleh media kerikil yaitu $5,23 \mathrm{~cm}$, hal ini dikarenakan kerikil tidak mengandung nutrisi dan kemampuannya dalam mengikat unsur hara rendah untuk awal pertumbuhan tanaman. Yury (1994) menyatakan bahwa kerikil tidak mengandung nutrisi dan apabila sistem tidak menyediakan air terus menerus, akar tanaman dapat mengering.

Tabel 1. Pengaruh media tanam hidroponik terhadap tinggi tanaman

\begin{tabular}{lrrr}
\hline \multirow{2}{*}{ Perlakuan } & \multicolumn{3}{c}{ Pengamatan Tinggi Tanaman $(\mathrm{cm})$} \\
\cline { 2 - 4 } & $14 \mathrm{HST}$ & $28 \mathrm{HST}$ & $35 \mathrm{HST}$ \\
\hline M1 = Arang sekam & $6,70 \mathrm{~b}$ & $9,73 \mathrm{~b}$ & $11,03 \mathrm{~b}$ \\
M2 $=$ Cocopeat & $8,33 \mathrm{c}$ & $9,56 \mathrm{~b}$ & $10,79 \mathrm{~b}$ \\
M3 $=$ Kapas & $5,80 \mathrm{~b}$ & $6,80 \mathrm{a}$ & $7,00 \mathrm{a}$ \\
M4 $=$ Kerikil & $5,23 \mathrm{a}$ & $9,61 \mathrm{~b}$ & $10,93 \mathrm{~b}$ \\
M5 $=$ Rockwool & $6,78 \mathrm{~b}$ & $8,92 \mathrm{~b}$ & $10,31 \mathrm{~b}$ \\
M6 $=$ Serbuk gergaji & $6,55 \mathrm{~b}$ & $9,64 \mathrm{~b}$ & $11,21 \mathrm{~b}$ \\
\hline
\end{tabular}

Hasil tinggi tanaman pada 28 dan 35 HST tidak menunjukkan perbedaan antar perlakuan arang sekam, cocopeat, kerikil, rockwool, dan serbuk gergaji sedangkan perlakuan kapas memberikan tinggi tanaman terendah berurutan yaitu 6,80 $\mathrm{cm}$ dan $7 \mathrm{~cm}$, hal ini dikarenakan media tanam kapas tidak dapat menyerap nutrisi dengan baik. Selain itu, kapas tidak mengandung unsur hara yang dapat mendukung kehidupan tanaman dalam jangka waktu yang lebih lama. Kandungan dominan kapas terdiri atas serat-serat tumbuhan (selulosa). Alasan utama pemakaian kapas sebagai media tanam adalah karena kapas dapat menjaga kelembapan yang lebih lama dan lebih baik daripada media tanah, sehingga tanaman yang ditanam di media kapas dapat tumbuh lebih cepat daripada di tanah. Tekstur kapas yang lembut sangat cocok untuk akar tanaman yang 
masih muda dan lemah, sehingga akar muda tersebut dapat berkembang lebih baik untuk jangka waktu tertentu (Lestari, 2009).

Setiap perlakuan media tanam memiliki kemampuan menyerap nutrisi yang berbeda, sehingga akan memengaruhi pada pertumbuhan dan perkembangan tanaman. Salah satu nutrisi yang berperan meningkatkan tinggi tanaman adalah unsur hara makro seperti N, P, dan K merupakan salah satu unsur makro yang penting dalam pertumbuhan vegetatif tanaman. Unsur makro merupakan unsur kimia yang dibutuhkan dalam jumlah besar untuk pertumbuhan dan perkembangan tanaman secara normal. Nitrogen juga berperan dalam pembentukan klorofil, asam amino, protein, DNA, dan RNA tanaman. Pertumbuhan vegetatif tanaman dapat dirangsang dengan aplikasi pemupukan $\mathrm{N}$, apabila aplikasi tidak teratur akan menyebabkan gejala defisiensi unsur $\mathrm{N}$ seperti klorosis, daun tua berwarna kuning, dan pertumbuhan tanaman terhambat sehingga akan menyebabkan penurunan hasil panen (Arteca, 2006).

\section{Pengaruh media tanam hidroponik terhadap jumlah daun}

Hasil analisis menunjukkan bahwa media tanam hidroponik berpengaruh terhadap jumlah daun (Tabel 2).

Tabel 2. Pengaruh media tanam hidroponik terhadap jumlah daun

\begin{tabular}{lrrr}
\hline \multirow{2}{*}{ Perlakuan } & \multicolumn{3}{c}{ Pengamatan Jumlah Daun (helai) } \\
\cline { 2 - 4 } & 14 HST & 28 HST & $35 \mathrm{HST}$ \\
\hline M1 = Arang sekam & $4,67 \mathrm{~b}$ & $8,00 \mathrm{~b}$ & $9.58 \mathrm{~b}$ \\
M2 = Cocopeat & $5,00 \mathrm{c}$ & $8,08 \mathrm{~b}$ & $9.33 \mathrm{~b}$ \\
M3 = Kapas & $3,92 \mathrm{a}$ & $5,08 \mathrm{a}$ & $4.75 \mathrm{a}$ \\
M4 = Kerikil & $5,08 \mathrm{c}$ & $8,08 \mathrm{~b}$ & $9.17 \mathrm{~b}$ \\
M5 = Rockwool & $5,08 \mathrm{c}$ & $7,75 \mathrm{~b}$ & $9.33 \mathrm{~b}$ \\
M6 $=$ Serbuk gergaji & $4,75 \mathrm{~b}$ & $8,25 \mathrm{~b}$ & $9.75 \mathrm{~b}$ \\
\hline
\end{tabular}

Umur 14 HST, jumlah daun tertinggi terdapat pada perlakuan cocopeat, kerikil dan rockwool, secara berurutan yaitu 5,00; 5,08 dan 5,08. Hal ini dikarenakan media tanam mampu menyerap unsur hara yang dapat mendukung pertumbuhan tanaman. Cocopeat atau serbuk sabuk kelapa menyerap air dengan baik dan mengandung unsur hara yaitu makro dan mikro seperti Kalium (K), Fosfor (P), Calsium (Ca), Magnesium (Mg), Natrium (Na). Namun, dari sekian banyaknya kandungan unsur hara yang dimiliki cocopeat. Pertumbuhan akar yang 
baik dan penyebaran yang lebih luas mampu menyerap nutrisi yang tersedia terutama unsur $\mathrm{N}$ yang sangat berperan dalam pertumbuhan daun sehingga dapat membantu pertambahan jumlah daun (Soeseno, 1991).

Media kerikil mempunyai pori-pori bagian bawah yang lebih besar sehingga dapat menyimpan air dan mempermudah akar tanaman untuk menyerap unsur hara yang diberikan (Yury, 1994). Media kerikil sintetis mampu mengikat air lebih baik dibandingkan kerikil alami.

Rockwool dapat menyerap air yang bagus sama halnya dengan cocopeat (Soeseno, 1991). Rockwool merupakan media anorganik dengan komponen media berbentuk granula yang berguna untuk menyerap dan meneruskan air sehingga mempunyai kapasitas memegang air tinggi. Rockwool dapat menghindarkan dari kegagalan semai akibat bakteri dan cendawan penyebab layu fusarium (Handreck \& Black, 1994).

Unsur hara yang digunakan pada hidroponik ini diperoleh dari nutrisi $\mathrm{AB}$ Mix yang mampu saling bekerja sama untuk merangsang pertumbuhan tanaman karena kandungan mineral yang menyebabkan berbagai unsur yang ada di dalam proses ini terlepas bebas secara berangsur-angsur sehingga mampu dimanfaatkan tanaman sebagai makanan. Selain nutrisi, menurut Fahrudin (2009) bahwa faktor lingkungan seperti suhu dan kelembaban udara juga mempengaruhi daun. Jika kelembaban udara terlalu rendah, suhu udara yang tinggi dan evapotranspirasi berlangsung terus menerus, maka tanaman akan kehilangan air dalam jumlah yang banyak, sehingga tekanan sel akan mengendur dan tanaman akan mulai layu dan tanaman tidak dapat menyerap air dan unsur hara secara optimal, sehingga proses penambahan daun juga terhambat. Daun berfungsi sebagai penghasil fotosintat yang sangat diperlukan tanaman sebagai sumber energi. Fotosintat yang dihasilkan akan mempercepat pertumbuhan dan perkembangan tanaman (Lukikariati dkk., 1996).

Menurut Chadirin (2001), semakin banyak jumlah daun, maka daun juga semakin luas (tidak saling menaungi) maka energi matahari yang dapat ditangkap untuk proses fotosintesis lebih banyak sehingga asimilat yang dihasilkan lebih tinggi dan tanaman yang mengalami kekeringan pada pertumbuhan vegetatif 
mempunyai daun lebih sempit dibandingkan tanaman yang memperoleh air cukup.

Jumlah daun umur 28 dan 35 HST menunjukkan tidak ada perbedaan perlakuan pada media tanam arang sekam, cocopeat, kerikil, rockwool, dan serbuk gergaji. Hal ini dikarenakan media tersebut dapat mengikat air dengan optimal sehingga akar dapat mengikat kuat, menyerap unsur hara dengan baik maka pertumbuhannya berkembang dengan baik. Media kapas memberikan jumlah daun terendah yaitu 5,08 (28 HST) dan 4,75 (35 HST), hal ini karena kapas memiliki stuktur yang lembut dan daya ikat unsur hara rendah, tetapi kapas dapat terjaga kelembaban dan juga memiliki persediaan air dalam jangka waktu yang lama. Umumnya kapas tahan terhadap kondisi menyimpan air dan pemakaian yang normal, tetapi jika air berlebihan kapas akan membusuk dengan warna kecoklatan dan bau busuk kapas tersebut mengakibatkan pertumbuhan jumlah daun yang berkurang (Purnama, 2008).

\section{Pengaruh media tanam hidroponik terhadap bobot segar dan bobot kering per tanaman}

Media tanam arang sekam, cocopeat, kerikil, rockwool, dan serbuk gergaji menunjukkan tidak ada perbedaan terhadap bobot segar per tanaman, hal ini karena media tersebut media yang baik untuk tanaman hidroponik. Berbeda dengan kapas yang memiliki bobot segar terendah sebesar 1,83 g (Tabel 3). Pada prinsipnya pemakaian media tanam hidroponik adalah yang tidak menekan pertumbuhan akar, dapat menolong peredaran larutan unsur hara dan udara.

Tabel 3. Pengaruh media tanam hidroponik terhadap bobot segar dan bobot kering per tanaman

\begin{tabular}{lcc}
\hline \multicolumn{1}{c}{ Perlakuan } & $\begin{array}{c}\text { Rerata bobot segar per } \\
\text { tanaman }(\mathrm{g})\end{array}$ & $\begin{array}{c}\text { Rerata Bobot kering per } \\
\text { tanaman }(\mathrm{g})\end{array}$ \\
\hline M1 $=$ Arang sekam & $12,50 \mathrm{~b}$ & $0,10 \mathrm{ab}$ \\
M2 $=$ Cocopeat & $13,92 \mathrm{~b}$ & $0,10 \mathrm{ab}$ \\
M3 $=$ Kapas & $1,83 \mathrm{a}$ & $0,04 \mathrm{a}$ \\
M4 $=$ Kerikil & $18,58 \mathrm{~b}$ & $0,13 \mathrm{c}$ \\
M5 $=$ Rockwool & $10,67 \mathrm{~b}$ & $0,10 \mathrm{~b}$ \\
M6 $=$ Serbuk gergaji & $16,75 \mathrm{~b}$ & $0,11 \mathrm{ab}$ \\
\hline
\end{tabular}


Pengaruh media tanam hidroponik terhadap bobot kering tanaman menunjukkan bahwa kerikil memiliki bobot kering per tanaman tertinggi yaitu 0.13 g. Hal ini diduga kerikil memiliki tekstur yang lebih baik untuk tanaman kailan, mudah basah, dan pada penelitian ini menggunakan sistem NFT pada hidroponik dimana nutrisi yang terlarut dalam air terus menerus mengalir. Menurut Israhadi (2009) bahwa kerikil adalah salah satu media tanam hidroponik anorganik yang komponennya berasal dari benda mati, tidak menyediakan nutrisi bagi tanaman, tetapi mempunyai pori-pori makro yang seimbang, sehingga aerasi cukup baik, dan tidak mengalami pelapukan dalam jangka pendek.

Hasil bobot kering juga sesuai dengan hasil tinggi tanaman, jumlah daun, dan bobot segar tanaman yang tinggi. Hal ini dikarenakan bobot kering dipengaruhi oleh besarnya fotosintat, tidak terlepas dari kandungan unsur hara yang tersedia sampai batas tertentu. Hal ini sesuai dengan pendapat Gardner et al. (1991), bahwa berat kering tanaman merupakan cerminan dari efisiensi penyerapan unsur hara dan pemanfaatan sinar matahari sepanjang musim pertumbuhan oleh tajuk tanaman.

\section{KESIMPULAN}

Media tanam berpengaruh terhadap pertumbuhan dan hasil tanaman kailan pada hidroponik dengan sistem NFT. Media tanam arang sekam, cocopeat, kerikil, rockwool dan serbuk gergaji memberikan hasil yang tinggi terhadap tinggi tanaman, jumlah daun, bobot segar per tanaman dan media kerikil yang memberikan nilai tertinggi terhadap bobot kering tanaman.

\section{DAFTAR PUSTAKA}

Adam, A. A. 2017. Hidroponik Untuk Pemula. Unsrat Press, Manado.

Agoes, D. S. 1994. Aneka Jenis Media Tanam dan Penggunaannya. Penebar swadaya, Jakarta.

Arteca, R. H. 2006. Introduction to Horticultural Science. Canada: Thomson Delmar Learning. 
Chadirin, Y. 2007. Terknologi Greenhouse dan Hidroponik. Skripsi. IPB, Bogor. http://repository.ipb.ac.id/jspui/. Diakses 14 Mei 2020.

Fahrudin F. 2009. Budidaya caisim (Brassica juncea L.) menggunakan estrak teh dan pupuk kascing. Skripsi. Fakultas Pertanian, Universitas Sebelas Maret, Surakarta.

Gardner, F.P., R.B. Pearce, Hoger L. M. 1991. Fisiologi Tanaman Budidaya. (Terjemahan). UI Press, Jakarta.

Handreck, K.A. \& N.D. Black. 1994. Growing Media for Ornamental Plant and Turf. University of New South Wales Press, Randwick NSW, Australia.

Hendra, H. A. \& A. Andoko. 2014. Bertanam Sayuran Hidroponik Ala Paktani Hydrofarm. Agromedia Press, Jakarta.

Irianto, 2012. Pertumbuhan dan Hasil Kailan (Brassica oleraceae) pada Berbagai Dosis Limbah Cair Sayuran. Skripsi. Jurusan Budidaya Pertanian Fakultas Pertanian Universitas Jambi. Jambi.

Israhadi. 2009. Pengaruh Macam dan Kepekatan Larutan Ekstrak Kompos sebagai Sumber Nutrisi pada Perbesaran Bibit Adenium sp. dengan Sistem Hidroponik Substrat. Skripsi. Fakultas Pertanian, UNS. Surakarta.

Istiqomah, S. 2006. Menanam Hidroponik. Azka Press, Jakarta.

Lestari, G. 2009. Berkebun Sayuran Hidroponik di Rumah. Prima Info Sarana, Jakarta.

Lukitariati S., N. L. P. Indriyani, A. Susiloadi, \& M. J. Anwarudin. 1996. Pengaruh Naungan dan Konsentrasi Asam Indol Butirat terhadap Pertumbuhan Bibit Batang Bawah Manggis. Jurnal Hortikultura, 6 (3): 220226.

Pracaya. 2005. Kol alias Kubis. Penebar Swadaya, Jakarta.

Prihmantoro, H dan Y. H. Indriani. 1999. Hidroponik Sayuran Semusim Untuk Bisnis dan Hobi. Penebar Swadaya, Jakarta.

Purnama, D. 2008. Pengaruh media tanama terhadap pertumbuhan dan perkembangan tanaman kacang hijau. http://pengaruhmediatanam terhadap perkembangan pertumbuhan.ht.ac.id. Diakses pada 14 Mei 2020.

Rahimah, D.S., 2012. Hidroponik di Bawah Langit. TRUBUS No. 513 Edisi Agustus 2012/XLIII. 
Rahmawati, E. 2018. Pengaruh Berbagai Jenis Media Tanam Dan Konsentrasi Nutrisi Larutan Hidroponik Terhadap Pertumbuhan Tanaman Mentimun Jepang (Cucumis Sativus L.). Skripsi. Fakultas Sains dan Tekonologi, UIN Alauddin Makassar. http://repositori.uinalauddin.ac.id/10748/1/Elma\%20Rahmawati.pdf. Diakses 6 Juni 2020.

Rosliani, R. \& N. Sumarni. 2005. Budidaya Tanaman Sayuran dengan Teknik Hidroponik. Balai Penelitian Tanaman Sayuran Pusat Penelitian dan Pengembangan Hortikultura Badan Penelitian dan Pengembangan Pertanian. Jakarta.

Samadi, B. 2013. Budidaya Intensif Kailan Secara Organik dan Anorganik. Pustaka Mina, Jakarta.

Soeseno, S. 1991. Bertanam Secara Hidroponik. Gramedia, Jakarta.

Yury, F. D. 1994. Bercocok Tanam Tanpa Tanah Hidroponik dan Bonsai. CV. Bahagia Batang, Pekalongan. 